\title{
Reproductive sources and sinks within a sea urchin, Evechinus chloroticus, population of a New Zealand fjord
}

\author{
Stephen R. Wing ${ }^{1, *}$, Mark T. Gibbs ${ }^{2}$, Miles D. Lamare ${ }^{1}$ \\ ${ }^{1}$ Department of Marine Science, PO Box 56, University of Otago, Dunedin, New Zealand \\ ${ }^{2}$ Cawthron Institute, Private Bag 2, Nelson, New Zealand
}

\begin{abstract}
We examined population structure of New Zealand sea urchins Evechinus chloroticus across the Doubtful-Thompson Sound complex, a fjord with a large influx of freshwater, a low salinity surface layer and a mean estuarine circulation. Measurements of abundance, growth, gonad development and larval settlement were collected at 9 sites. We observed large differences in each of these vital population parameters among sites. The highest growth rates and gamete production occurred at the entrances of the fjord. We used 3 alternative growth models to test whether the spatial pattern in growth rates was robust. Variability in growth among sites likely reflected differences in nutritional history, as indicated by the Aristotle's lantern index. Size distributions taken 2 yr apart at each of the 9 sites showed that the adult mode was relatively stable in time. As a consequence much of the variance in mean size among sites could be explained by differences in growth rather than in mortality or recruitment. The highest abundance and aggregation of sea urchins occurred at mid-fjord and entrance sites, which coincided with the highest rates of larval settlement and suggested limited larval supply elsewhere. The observed spatial patterns in vital rates were used to evaluate the likely influences of spatial heterogeneity in larval production on larval dispersal patterns within the fjord, based on particle movements within a validated hydrodynamic model. We then tested the sensitivity of these model results to magnitude of wind and rainfall events and duration of larval development. Results from our field observations and modeling studies suggest that the sea urchin population in Doubtful-Thompson Sound is likely composed of distinct areas of reproductive source and sink.
\end{abstract}

KEY WORDS: Sea urchin · Fjord · Metapopulation · Larval dispersal · Growth · Recruitment Resale or republication not permitted without written consent of the publisher -

\section{INTRODUCTION}

For sedentary marine invertebrates and fishes with long-lived, and potentially far-ranging larval stages, the patterns of larval dispersal within a population network can result in a decoupling of local gamete production with larval supply and recruitment. In the extreme case, segments of these marine metapopulations can be non-reproductive subpopulations, or pseudopopulations, in which recruits survive but do not produce successful larvae. In this case, local reproductive rate is far less than mortality, and thus maintenance of abundance in these subpopulations entirely depends

*Email: steve.wing@stonebow.otago.ac.nz on immigration from productive larval source areas elsewhere in the population network. If source areas in these networks produce a large number of successful propagules, it is possible that a high proportion of the regional population network can be maintained within habitats with a local reproductive deficit. In such systems, assumptions about the productivity and resilience of populations to harvest pressure, drawn from estimates of local demographic parameters, can be particularly misleading. Metapopulations of this type can be subject to sudden collapse under widespread degradation of habitat or exploitation that results in loss or decline of larval source populations. Quinn et al. 
(1993) found this to be the likely case for some sea urchin populations that exhibited both strong spatial variability in vital rates and reproductive Allee effects.

Sea urchins exert a critical influence on subtidal communities through grazing on attached macroalgae and invertebrates. Evidence for this influence has been documented in numerous cases from both temperate and tropical reef systems where large-scale mortality of sea urchin populations results in release of macroalgal assemblages from grazing pressure. In most cases these systems have moved from an 'urchin barren' condition to one with more productive macroalgal growth following the mass mortality (Pearse \& Hines 1979, Miller \& Colodey 1983, Fletcher 1987, Raymond \& Scheibling 1987, Carpenter 1990). As sea urchin populations increase in an area they may graze abundant macroalgal and invertebrate assemblages down to relatively low diversity 'barrens', where only encrusting coralline algae and crevice dwelling organisms persist. These high density populations of sea urchins are able to persist with very low nutritional input by feeding on microalgal films. One of the common patterns in these systems is that urchin barrens are maintained as an alternative state to productive macroalgal communities. The assumption that follows is that areas supporting dense populations of sea urchins would support productive macroalgal communities if the sea urchins were removed. This is clearly not the case in the low productivity environments of the inner New Zealand fjords where sea urchins persist with relatively static growth rates (Wing et al. 2001).

Here we consider the spatial structure of a population of the endemic sea urchin Evechinus chloroticus in the Doubtful-Thompson Sound complex, a fjord system on the southwest coast of New Zealand's South Island. E. chloroticus has a strong influence on New Zealand's shallow subtidal rocky reefs by intensively grazing on macroalgae and encrusting invertebrates (Ayling 1981, Andrew 1986). This species reproduces via planktotrophic larvae that are spawned in spring and summer and complete their development in approx. 1 mo (Dix 1970a, Walker 1984, Lamare \& Barker 1999). Following settlement, juveniles grow at a rate of 10 to $15 \mathrm{~mm} \mathrm{yr}^{-1}$, becoming reproductively mature at a size of approximately 30 to $50 \mathrm{~mm}$ test diameter (Dix 1970b, Lamare \& Mladenov 2000). Larval dispersal is high in most populations and is reflected in the lack of genetic differentiation in E. chloroticus along the New Zealand coast. One exception is the genetically distinct population in Doubtful Sound, where restricted larval transport occurs (Mladenov et al. 1997, C. Perrin unpubl. data).

At the time of our study, Evechinus chloroticus had not been exploited in most of Fiordland, therefore rep- resenting one of the few large populations of sea urchins whose abundance and distribution were not directly influenced by humans, and thus reflected the influences of natural processes. Predation occurs primarily from rock lobsters Jasus edwardsii, blue cod Parapercis colias, and the seastar Coscinasterias muricata, and is greatest on the cryptic juveniles (Andrew \& Choat 1982, Andrew \& MacDiarmid 1991). Nutritional history can be inferred by the size of the Aristotle's lantern relative to test diameter, as there is demonstrated plasticity in resource allocation between the test and feeding structure (Ebert 1980a, McShane \& Anderson 1997). These characteristics of the E. chloroticus population in Doubtful-Thompson Sound make it a useful model for testing ideas about spatial population structure and patterns of larval sources and sinks of marine populations across heterogeneous environments.

In this study we tested for significant differences in Arisotle's lantern index, mean test diameter, growth, gonad development, settlement and adult density over 2 yr among 9 sites across the Doubtful-Thompson Sound complex (Fig. 1a). Because these measures are effective proxies for the vital rates of this population we were able to examine the full life cycle of Evechinus chloroticus within Doubtful-Thompson Sound and consider patterns in growth and reproduction in the context of the physical environment in the Sound. Specifically we tested whether patterns in adult size structure and gonad development could be explained by variability in Aristotle's lantern index and growth rate among sites. This allowed us to assess whether a nutritional control on gamete production was likely. We tested for covariance of density with settlement among sites. We could then assess whether patterns in abundance were likely influenced by larval supply. Finally because Doubtful-Thompson Sound is a semiclosed system we were able to investigate the larval transport patterns that likely link the 2 processes. We used a 3D hydrodynamic model to infer patterns in transport and retention of larvae in the Sound and their sensitivity to the observed patterns in larval production.

\section{MATERIALS AND METHODS}

Study site. The Doubtful-Thompson Sound complex $\left(45^{\circ} 30^{\prime} \mathrm{S}, 167^{\circ} 0^{\prime} \mathrm{E}\right)$ is one of 14 glacially carved fjords that indent the southwestern coast of New Zealand. In this complex, 2 fjords, Thompson Sound and Doubtful Sound, are joined by a relatively shallow reach. The large amount of freshwater entering the complex from both rainfall to the catchment (up to $7 \mathrm{~m} \mathrm{yr}^{-1}$ ) and input from the Manapouri Hydroelectric Powerplant $\left(450 \mathrm{~m}^{3}\right.$ 

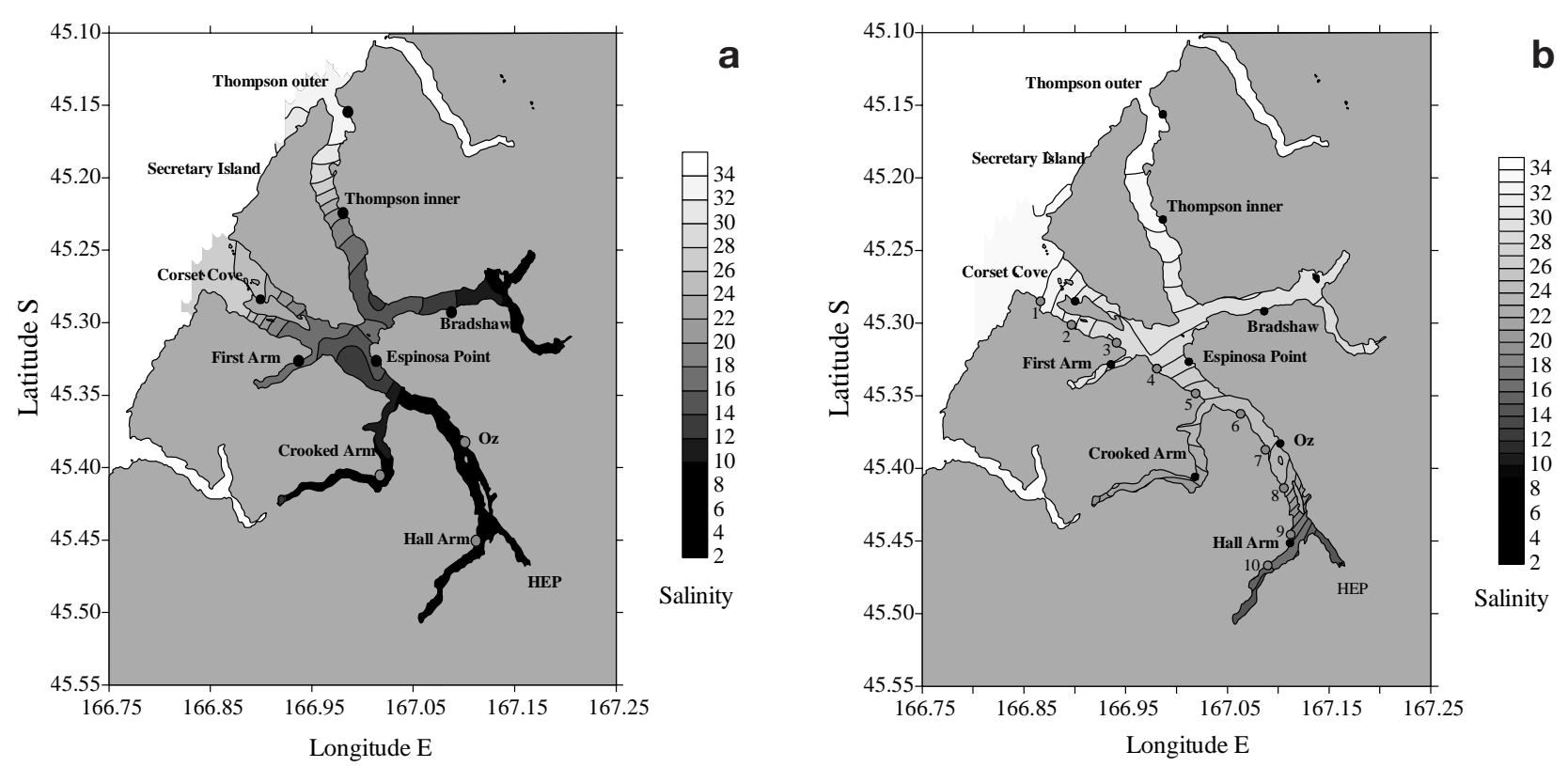

Fig. 1. Pattern in average salinity in the upper $2 \mathrm{~m}$ across the Doubtful-Thompson Sound complex for (a) November 1997 during high rainfall $\left(17 \mathrm{~mm} \mathrm{~d}^{-1}\right)$ and (b) February 1999 during low rainfall conditions $\left(3 \mathrm{~mm} \mathrm{~d}^{-1}\right)$. Positions of the 9 study sites, Thompson outer, Thompson inner, Bradshaw, Corset Cove, First Arm, Espinosa, Crooked Arm, Oz and Hall Arm, are indicated by labeled symbols. Ten sites used for the depth distribution survey are indicated by numbered symbols in (b)

$\mathrm{s}^{-1}$ ) alters the near-surface hydrography by maintaining a buoyant low-salinity layer (Stanton \& Pickard 1981, Gibbs et al. 2000). Continuity of mass demands that this freshwater layer flows in the seaward, or down-fjord, direction. In the absence of wind driven circulation the velocity shear associated with this seaward surface flow entrains small amounts of the underlying oceanic water, which is transported out of the fjord. In order to maintain continuity of salt within the fjord this loss must be replaced by an up-fjord flow of oceanic water in the layers beneath the low salinity layer. This estuarine or gravitational circulation is often the dominant circulation process in shallow estuaries. However estuarine circulation in fjords is typically more gradual as a result of the lack of turbulent mixing from the benthic boundary layer. Furthermore the recent study by Gibbs et al. (2000) shows that upfjord directed wind events often arrest or reverse estuarine circulation in Doubtful-Thompson Sound. In this process, strong onshore winds associated with atmospheric cold fronts are accelerated by the steep walls of the fjord, and the resulting surface flow opposes the down-fjord directed flow in the low salinity layer. These strong wind events may influence the fjord as often as 2 to 3 times a week and last 1 to $3 \mathrm{~d}$. During strong wind events, circulation in the low salinity layer may be in the up-fjord direction if the wind-forced flows overcome the estuarine circulation. However, during calm periods between the strong wind events, the freshwater retarded in the fjord during the periods of strong winds must flow out to sea and estuarine circulation during these periods can be strong. Hence, although the annual mean circulation in the upper layers of the fjord is estuarine, the flow in the low salinity layer on any particular day depends on the local winds (Gibbs et al. 2000). This weather-band variability is an important process influencing the dispersal of larvae in the fjord.

Size structure. We recorded the size frequency of adult sea urchins from each of the 9 sites during October and November 1997 and again during June 1999. Test diameter was measured using Vernier calipers for 100 to 500 sea urchins collected at 3 to $9 \mathrm{~m}$ depth from each site during each period. After measurement the sea urchins were returned to the collection site. We tested for differences in the size distributions taken during the 2 time periods with an approximate Kolmogorov-Smirnov test for goodness of fit between frequency distributions (Sokal \& Rohlf 1981). Values for mean size and variance in size were calculated for each site using the pooled distributions. We used 1-way ANOVA to test for differences in mean size among sites. A Bonferroni post-hoc test was then used to test for differences in mean size among pairwise comparisons.

Aristotle's lantern index and gonadal index. At each of the 9 sites we collected 15 to 18 adult sea urchins in January 1997, April, July and October 1998. For each sample we measured test diameter, total weight, gonad weight, test weight, and the average demi-pyramid 
length of the Aristotle's lantern. In the case of test diameter and demi-pyramid length we took averages of multiple measurements (2 to 3 ) to ensure that measurement error did not confound our results. We then used these data to calculate a gonadal index and Aristotle's lantern index for each site. Averages for each index were calculated among seasonal sampling. We calculated the expected test weight from test diameter so that the gonadal index was not biased by differences among sites in the relationship between test diameter and weight. We pooled 49 samples from each of the 9 sites and calculated the relationship between test diameter $(\mathrm{mm})$ and test weight $(\mathrm{g})$ using a power function. The relationship is described by:

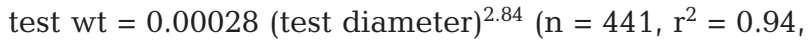
$\mathrm{p}<0.0001)$. The gonadal index was calculated by dividing gonad weight by the expected test weight. Per-capita gonad size was estimated for each site by multiplying the gonad index by the mean expected test weight from the size distribution above sexual maturity (30 to $50 \mathrm{~mm}$, Dix 1970b) and taking the mean and standard error among the 15 samples. We did not analyze size or age at gonad maturation at each site. However, size distributions typically showed very few animals below $60 \mathrm{~mm}$ and excluding the smaller sizes effectively removed only a small number of new recruits (10 to $20 \mathrm{~mm}$ ).

We removed excess tissue from the Aristotle's lanterns with $\mathrm{NaOH}$ and measured the demi-pyramids to the nearest $0.1 \mathrm{~mm}$ as described in Levitan (1992). Aristotle's lantern index was calculated from the regression between the natural logarithm of test diameter and the natural logarithm of the length of the demi-pyramid on the Aristotle's lantern (Ebert 1980a). The expected demi-pyramid length at each site was then calculated for an individual $100 \mathrm{~mm}$ in test diameter. We used ANCOVA to test the regressions of the natural logarithm of demi-pyramid length with the natural logarithm of test diameter among study sites for homogeneity of slopes. We then tested for significant differences between elevations of slopes among sites. We employed a Bonferroni post-hoc test for differences in elevation among pairwise comparisons of sites.

Growth increment data. During November 1997 we tagged 300 to 500 randomly selected adult sea urchins with calcein at each of the 9 sites between 3 and $9 \mathrm{~m}$ depth in Doubtful-Thompson Sound. For marking animals we prepared a solution of 1000 ppm calcein in $3 \mu \mathrm{m}$ Millipore-filtered seawater that had been sterilized for $5 \mathrm{~min}$. in a microwave oven. Divers injected 0.5 to $1 \mathrm{cc}$ of this solution in situ into each sea urchin, depending on size, using a sheep inoculation gun with \#14 needle. Each calcein-tagged sea urchin was carefully returned to its original position on the substratum.
During November 1998 approximately 100 sea urchins were collected from each site. Each sea urchin was measured for test diameter and its Aristotle's lantern was removed, measured and soaked in $\mathrm{NaOH}$. The demi-pyramids of each Aristotle's lantern were then illuminated under an ultraviolet light source to determine presence of calcein tags. For those demipyramids containing a fluorescent band we measured the increment of growth using a camera lucida. Numbers of tagged sea urchins recovered at each site ranged between 13 and 92 (see Table 4).

We used the relationship between the natural logarithm of demi-pyramid length and the natural logarithm of test diameter for each site to estimate sitespecific changes in test diameter from demi-pyramid growth increments. These growth increments, expressed in terms of change in test diameter, were then used to estimate the parameters of 3 alternative growth models.

Growth models. Von Bertalanffy: We used the growth increment data to calculate the parameters of the von Bertalanffy growth equation for each study site with a standard Walford plot technique (Walford 1946) where:

$$
L_{t}=L_{\infty}\left(1-\mathrm{e}^{-K t}\right)
$$

$L_{t}$ is the length at time $t, L_{\infty}$ is the average length at infinite time and $K$ is the growth constant.

Von Bertalanfy with variable $L_{\infty}$ : Parameters of the von Bertalanffy growth equation with a maximum likelihood estimate of variance in $L_{\infty}$ were calculated for each study site using a combination of growth increment and size frequency data by the methods of Smith et al. (1998). Because it was determined that size frequency distributions were relatively stable over the growth increment period, we used size frequency distributions representing the sum of 2 sample periods in this analysis. Here the size structure of the population is modeled with the von Foerster equation:

$$
\frac{\partial n(L, t)}{\partial t}=-\frac{\partial n}{\partial L}[n(L, t) g(L)]-D(L) n(L, t)
$$

which describes the number of individuals $(n)$ at length $L$ in terms of the size specific growth $g(L)$ and mortality $D(L)$ of the population (Botsford et al. 1994).

The maximum likelihood model used by Smith et al. (1998) incorporates Sainsbury's (1980) assumptions on individual variability in growth and includes parameters that allow $L_{\infty}$ and $K$ to be random variables. The method assumes that populations have steady state recruitment rates and are at stable size distribution, although its results are robust to some departures from these assumptions (Smith et al. 1998). In the context of this paper we require that the model only measure variance in $L_{\infty}$ by taking the sum of 2 negative ln like- 
lihood functions, one from the growth increment data and one from the size distribution data (Smith et al. 1998, Morgan et al. 2000).

Richards model: We estimated parameters of the Richards s-shaped growth equation for each study site using the maximum likelihood fit of a non-linear regression model (Ebert 1980b):

$$
L_{t}=L_{\infty}\left(1-\mathrm{e}^{-K t}\right)^{-a}
$$

where $a$ is the shape parameter.

Abundance and depth distribution. We measured the depth distribution of sea urchins at 10 evenly placed sites along the axis of Doubtful Sound from Hall Arm to Corset Cove (Fig. 1b). Line transects were placed from the high tide mark on the rock wall to $20 \mathrm{~m}$ depth and we counted sea urchins in paired $1 \mathrm{~m}^{2}$ quadrates positioned at each meter along the transect line. A total of 596 quadrates were studied in this manner. We used the data to determine the mean depth distribution and patterns of abundance of sea urchins with depth in order to make accurate comparisons of mean abundance among sites.

Based on the results of the depth distribution survey, we surveyed abundance of adult sea urchins using a stratified random sampling design. SCUBA divers randomly placed $2 \mathrm{~m}^{2}$ quadrates just below the low salinity layer at 3 to $6 \mathrm{~m}$, and in a second stratum between the 6 to $9 \mathrm{~m}$ depth contours. Sample size ranged between 77 and 212 quadrates per site with equal sampling effort in each depth range. We pooled the data between 3 and $9 \mathrm{~m}$ depth to estimate density (ind. $\mathrm{m}^{-2}$ ) by site. Surveys were replicated at 4 locations along a $200 \mathrm{~m}$ stretch of the fjord at each study site. We transformed the quadrate data using $\ln ($ abundance +1 ) to achieve a normal distribution, and then used 1-way ANOVA to test for differences in density among sites. Results from a Bonferroni post-hoc test indicated differences in mean density among pairwise comparisons. We calculated the variance-to-mean ratio for each site and converted these values to an 'index of dispersion $(I)^{\prime}$, where $I=\left(\mathrm{s}^{2} / x\right)(n-1)$, where $s^{2}=$ variance, $x=$ mean and $n=$ sample size (Andrew \& Mapstone 1987). We then tested $I$ for departures from unity using a $\chi^{2}$ distribution with $(n-1)$ degrees of freedom.

Larval settlement. We deployed 4 settlement collectors at 10 to $12 \mathrm{~m}$ depth on moorings at each site, corresponding to observation of the depth of larval distribution patterns and settlement of juveniles (Lamare 1998). Each collector consisted of a PVC pipe $(170 \mathrm{~mm}$ diameter, $185 \mathrm{~mm}$ length) that contained 12 circular sheets of light diffuser panels (Harrold et al. 1991). A large vane $(100 \times 300 \mathrm{~mm}) \mathrm{kept}$ the sampler oriented to water flow. SCUBA divers retrieved and replaced the 36 collectors at each sampling occasion. Sample intervals were approximately monthly during November through January, the peak period in sea urchin settlement in Doubtful-Thompson Sound (Lamare 1998). We washed the collectors in freshwater and checked the accumulated material for the presence of juvenile Evechinus chloroticus. To resolve spatial differences in settlement we summed settlement over the $2 \mathrm{yr}$ period for each collector and then calculated the standard error among collectors at each site.

Hydrographic surveys. We conducted 3 fine-scale hydrographic surveys of Doubtful-Thompson Sound using a Seabird SBE 19 CTD profiler on October 9, 1997, October 10, 1998 and February 10, 1999. For each survey we collected CTD data from the upper $100 \mathrm{~m}$ of the water column with 30 to 48 separate casts at 2 to $3 \mathrm{~km}$ intervals throughout the fjord complex. Data were post-processed using standard Seabird processing algorithms for the pumped SBE-19. These surveys were scheduled during periods of high average rainfall and low average rainfall, based on $2 \mathrm{wk}$ running averages. Rainfall data were obtained from the National Institute of Water and Atmosphere (NIWA) weather station \#F56280 on Secretary Island ( $\left.45^{\circ} 13.26^{\prime} \mathrm{S}, 166^{\circ} 53.16^{\prime} \mathrm{E}\right)$.

Temperature time-series. We collected temperature time series from moorings deployed at each study site. On each mooring Tidbit $^{\Theta}$ temperature loggers (Onset Computer) were deployed every $2 \mathrm{~m}$ from the surface to $20 \mathrm{~m}$ depth. The sensors collected temperature readings every $10 \mathrm{~min}$ through the winter months (April to October). In winter the cold $\left(2\right.$ to $\left.11^{\circ} \mathrm{C}\right)$ low salinity layer is distinct from the underlying seawater (12 to $15^{\circ} \mathrm{C}$ ) (Gibbs et al. 2000). These temperature data were then used to measure the depth of the low salinity surface layer during a series of rainfall events.

\section{RESULTS}

\section{Size structure of the population}

At each site we observed only small differences in size distributions of adult sea urchins collected during 1997 and 1999 (Fig. 2). There were no apparent transient cohorts in the distributions, each being unimodal with a stable adult mode. Results from the approximate Kolmogorov-Smirnov test for goodness-of-fit indicated that the pooled size distributions for inner and outer fjord sites did not change significantly between November 1997 and June 1999 (inner sites D = 0.1405, $p>0.05$, outer sites $D=0.1325, p>0.05$ ). Furthermore we found no significant changes in mean size between time periods among the 9 sites. These results indicated that because we had relatively stable size frequency distributions we could use the methods of Smith et al. (1998) to estimate the parameters of the von Bertalanffy growth equation with variance in $L_{\infty}$. 


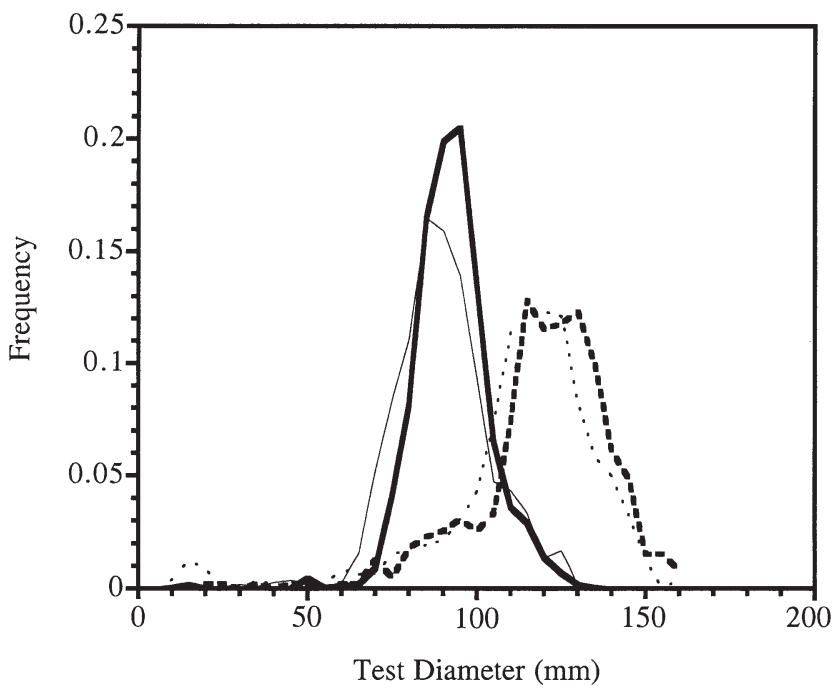

Fig. 2. Evechinus chloroticus. Pooled size distributions of sea urchins from inner fjord sites: Hall Arm, Oz, Bradshaw, Thompson inner, Crooked Arm and First Arm in 1997 (thick solid line) and 1999 (thin solid line). Pooled distributions from outer fjord sites: Corset Cove, Thompson outer and Espinosa Point in 1997 (thick dashed line) and 1999 (thin dashed line)

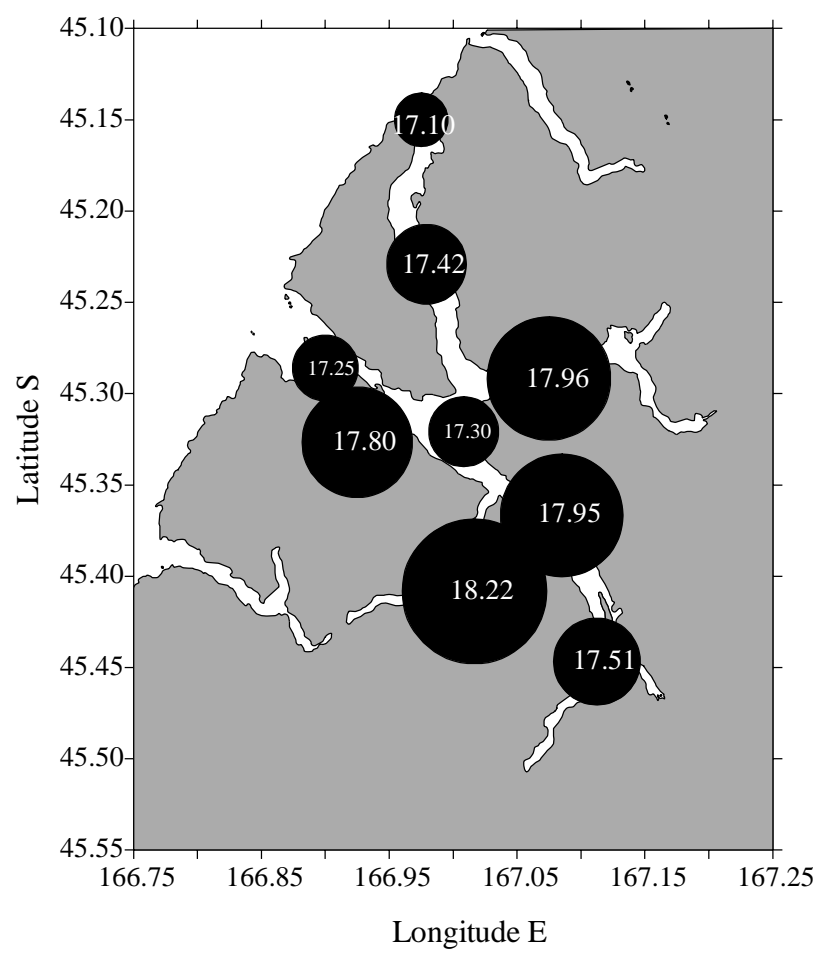

Fig. 3. Evechinus chloroticus. Aristotle's lantern index in Doubtful-Thompson Sound, indicated by the expected length of the demi-pyramid $(\mathrm{mm})$ for a sea urchin of $100 \mathrm{~mm}$ test diameter. Diameter of circles is proportional to mean Aristotle's lantern index and indicates poor nutritional history in the inner fjord sites

\section{Aristotle's lantern index}

The relative size of the Aristotle's lantern was relatively small at the 2 entrance sites (Thompson outer, Corset Cove) and mid-fjord sites (Thompson inner and Espinosa Point), and large in the arms of the fjord (Bradshaw, First Arm, Crooked Arm, Oz). However, the site at Hall Arm had lantern sizes only slightly larger than mid-fjord sites (Fig. 3). A linear regression of lantern size on test diameter for each site indicated that much of the variance in demi-pyramid length could be explained by test diameter (Table 1). Slopes were found to be homogenous at most sites (Table 2). For those regressions with homogenous slopes, ANCOVA indicated significant differences in magnitude of regression lines among sites $\left(F_{8,1190}=27.3\right.$, $\mathrm{p}=0.0001)$. The Bonferonni post-hoc test for each paired comparison showed significant differences between sites with large lanterns (Crooked Arm, Bradshaw, Oz and First Arm) and the other sites (Espinosa Point, Thompson outer and Corset Cove) (Table 2). There were significant differences between the site at inner Thompson Sound, which had intermediate lantern sizes, with all sites except Hall Arm and Bradshaw Sound. There were no significant differences between outer Thompson Sound, Corset Cove, Espinosa Point and Hall Arm.

\section{Mean size}

The mean size of sea urchins at the entrances of the fjord, calculated from the combined size frequency data from each study site, was between 111 and $116 \mathrm{~mm}$. Mean sizes declined at mid-fjord and in the arms of the fjord to between 85 and $90 \mathrm{~mm}$. Results from the 1-way ANOVA indicated significant differences among sites $\left(F_{8,5236}=383, \mathrm{p}=0.0001\right)$. Results from the Bonferroni post-hoc test showed that there were significant differ-

Table 1. Linear regressions between the natural logarithm of demi-pyramid length $(y)$ and the natural logarithm of test diameter $(x)$ with $r^{2}$ values and sample sizes given for each site in the first 4 columns

\begin{tabular}{|lcccc|}
\hline Site & $y$-intercept & Slope & $r^{2}$ & $\begin{array}{c}\text { Sample } \\
\text { size }\end{array}$ \\
\hline Crooked Arm & -0.98 & 0.844 & 0.81 & 143 \\
Bradshaw Sound & -0.66 & 0.769 & 0.76 & 170 \\
Oz & -0.35 & 0.704 & 0.80 & 159 \\
First Arm & -0.18 & 0.663 & 0.76 & 135 \\
Hall Arm & -1.22 & 0.886 & 0.93 & 74 \\
Thompson inner & -0.33 & 0.691 & 0.78 & 145 \\
Espinosa Point & -0.49 & 0.725 & 0.82 & 103 \\
Corset Cove & -1.11 & 0.860 & 0.71 & 75 \\
Thompson outer & -1.08 & 0.851 & 0.82 & 129 \\
\hline
\end{tabular}


ences between mean size at the 2 entrance sites, and Espinosa Point with the other sites (Table 3). We observed covariance between mean size and Aristotle's lantern index among sites $\left(\mathrm{r}^{2}=0.55, \mathrm{p}=0.02\right)$.

\section{Growth models}

Our estimates of the growth parameter $L_{\infty}$ using 3 alternative growth models, indicated that the pattern observed among sites was robust to differences between these 3 models (Table 4 ). In each of the models the mean size at infinite time $\left(L_{\infty}\right)$ was large at the 2 entrance sites and decreased at the mid-fjord and in the arms of the fjord (Fig. 4). $L_{\infty}$ for each of the growth models covaried with mean size among sites (von Bertalanffy $\mathrm{r}^{2}=0.92, \mathrm{p}<0.0001$; von Bertalanffy with variance in $L_{\infty}, \mathrm{r}^{2}=0.96, \mathrm{p}<0.0001$; Richards $\mathrm{r}^{2}=0.90$, $\mathrm{p}<0.0001$ ) (Fig. 5). The Aristotle's lantern index covaried with $L_{\infty}$ from each of the growth models as

Table 2. Probability values for Bonferonni post-hoc test on regressions between lantern length and test diameter between pairs of sites. Asterisks indicate those site combinations where the slopes of regressions are not homogenous. Significant differences are indicated in bold

\begin{tabular}{|c|c|c|c|c|c|c|c|c|}
\hline & $\begin{array}{c}\text { Crooked } \\
\text { Arm }\end{array}$ & $\begin{array}{l}\text { Bradshaw } \\
\text { Sound }\end{array}$ & $\mathrm{Oz}$ & $\begin{array}{l}\text { First } \\
\text { Arm }\end{array}$ & $\begin{array}{l}\text { Hall } \\
\text { Arm }\end{array}$ & $\begin{array}{c}\text { Thompson } \\
\text { inner }\end{array}$ & $\begin{array}{c}\text { Espinosa } \\
\text { Point }\end{array}$ & $\begin{array}{l}\text { Corset } \\
\text { Cove }\end{array}$ \\
\hline \multicolumn{9}{|l|}{ Crooked Arm } \\
\hline Bradshaw Sound & 0.256 & & & & & & & \\
\hline $\mathrm{Oz}$ & $1.0^{*}$ & 0.010 & & & & & & \\
\hline First Arm & $1.0^{*}$ & 0.001 & 1.0 & & & & & \\
\hline Hall Arm & 0.0001 & 0.003 & $0.0001^{*}$ & $0.0001^{*}$ & & & & \\
\hline Thompson inner & $0.019^{*}$ & 1.0 & 0.0001 & 0.0001 & $0.076^{*}$ & & & \\
\hline Espinosa Point & 0.0001 & 0.0001 & 0.0001 & 0.0001 & 1.0 & 0.001 & & \\
\hline Corset Cove & 0.0001 & 0.003 & $0.0001^{*}$ & $0.0001^{*}$ & 1.0 & $0.006^{*}$ & 1.0 & \\
\hline Thompson outer & 0.0001 & 0.0001 & $0.0001^{*}$ & $0.0001^{*}$ & 1.0 & $0.0001^{*}$ & 1.0 & 1.0 \\
\hline
\end{tabular}

Table 3. Probability values for Bonferonni post-hoc test on pairwise comparisons of mean test diameter. Significant differences are indicated in bold

\begin{tabular}{|llllllll|}
\hline & $\begin{array}{c}\text { Crooked } \\
\text { Arm }\end{array}$ & $\begin{array}{c}\text { Bradshaw } \\
\text { Sound }\end{array}$ & Oz & $\begin{array}{c}\text { First } \\
\text { Arm }\end{array}$ & $\begin{array}{c}\text { Hall } \\
\text { Arm }\end{array}$ & $\begin{array}{c}\text { Thompson } \\
\text { inner }\end{array}$ & $\begin{array}{c}\text { Espinosa } \\
\text { Point }\end{array}$ \\
$\begin{array}{l}\text { Crooked Arm } \\
\text { Bradshaw Sound }\end{array}$ & 0.206 & & & & \\
Oz & $\mathbf{0 . 0 0 5}$ & 1.0 & & & & \\
First Arm & 1.0 & 1.0 & 0.074 & & & \\
Hall Arm & $\mathbf{0 . 0 0 0 1}$ & $\mathbf{0 . 0 4 1}$ & 0.515 & $\mathbf{0 . 0 0 0 1}$ & & \\
Thompson inner & 1.0 & 1.0 & $\mathbf{0 . 0 0 0 1}$ & 1.0 & $\mathbf{0 . 0 0 0 1}$ & & \\
Espinosa Point & $\mathbf{0 . 0 0 0 1}$ & $\mathbf{0 . 0 0 0 1}$ & $\mathbf{0 . 0 0 0 1}$ & $\mathbf{0 . 0 0 0 1}$ & $\mathbf{0 . 0 0 0 1}$ & $\mathbf{0 . 0 0 0 1}$ & $\mathbf{0 . 0 0 0 1}$ \\
Corset Cove & $\mathbf{0 . 0 0 0 1}$ & $\mathbf{0 . 0 0 0 1}$ & $\mathbf{0 . 0 0 0 1}$ & $\mathbf{0 . 0 0 0 1}$ & $\mathbf{0 . 0 0 0 1}$ & $\mathbf{0 . 0 0 0 1}$ & $\mathbf{0 . 0 0 0 1}$ \\
Thompson outer & $\mathbf{0 . 0 0 0 1}$ & $\mathbf{0 . 0 0 0 1}$ & $\mathbf{0 . 0 0 0 1}$ & $\mathbf{0 . 0 0 0 1}$ & $\mathbf{0 . 0 0 0 1}$ & $\mathbf{0 . 0 0 0 1}$ & $\mathbf{0 . 0 0 0 1}$ \\
\hline
\end{tabular}

Table 4. Parameter values for the von Bertalanffy function, von Bertalanffy with variance in $L_{\infty}$, and Richards growth function. $\mathrm{R}^{2}$ values are given for fitting difference equations to the von Bertalanffy and Richards models. $K$ is the growth constant

\begin{tabular}{|c|c|c|c|c|c|c|c|c|c|c|}
\hline \multirow[t]{2}{*}{ Site } & \multicolumn{2}{|c|}{$\begin{array}{l}\text { von Bertalanffy } \\
\text { with nonvarying } L_{\infty}\end{array}$} & \multicolumn{3}{|c|}{$\begin{array}{c}\text { von Bertalanffy } \\
\text { with variance in } L_{\infty}\end{array}$} & \multicolumn{4}{|c|}{$\begin{array}{l}\text { Richards } \\
\text { function }\end{array}$} & \multirow{2}{*}{$\begin{array}{c}\text { Sample } \\
\text { size } \\
\mathrm{N}\end{array}$} \\
\hline & $L_{\infty}$ & K & $r^{2}$ & $L_{\infty}(\mathrm{SE})$ & $K$ & $L_{\infty}$ & $K$ & $\mathrm{n}$ & $\mathrm{r}^{2}$ & \\
\hline Crooked Arm & 95.2 & 0.24 & 0.92 & $91(16)$ & 0.405 & 95.22 & 0.28 & 0.22 & 0.94 & 32 \\
\hline Bradshaw Sound & 99.8 & 0.21 & 0.82 & $94.5(14)$ & 0.333 & 98.43 & 0.23 & 0.18 & 0.96 & 13 \\
\hline $\mathrm{Oz}$ & 103.2 & 0.18 & 0.94 & $94.9(12.6)$ & 0.356 & 97.95 & 0.25 & 0.21 & 0.95 & 23 \\
\hline First Arm & 87.2 & 0.31 & 0.96 & $89.8(15.7)$ & 0.406 & 86.81 & 0.36 & 0.27 & 0.93 & 34 \\
\hline Hall Arm & 101.6 & 0.31 & 0.96 & $92.7(25)$ & 0.366 & 98.76 & 0.37 & 0.29 & 0.96 & 22 \\
\hline Thompson inner & 99.7 & 0.20 & 0.96 & $91(13)$ & 0.338 & 97.04 & 0.27 & 0.20 & 0.97 & 28 \\
\hline Espinosa Point & 107.4 & 0.23 & 0.92 & $99.5(24)$ & 0.300 & 102.56 & 0.32 & 0.25 & 0.97 & 92 \\
\hline Corset Cove & 131.7 & 0.39 & 0.96 & $124(21)$ & 0.298 & 128.70 & 0.50 & 0.36 & 0.90 & 28 \\
\hline Thompson outer & 122.7 & 0.23 & 0.96 & 123 (18) & 0.307 & 117.26 & 0.32 & 0.25 & 0.95 & 30 \\
\hline
\end{tabular}




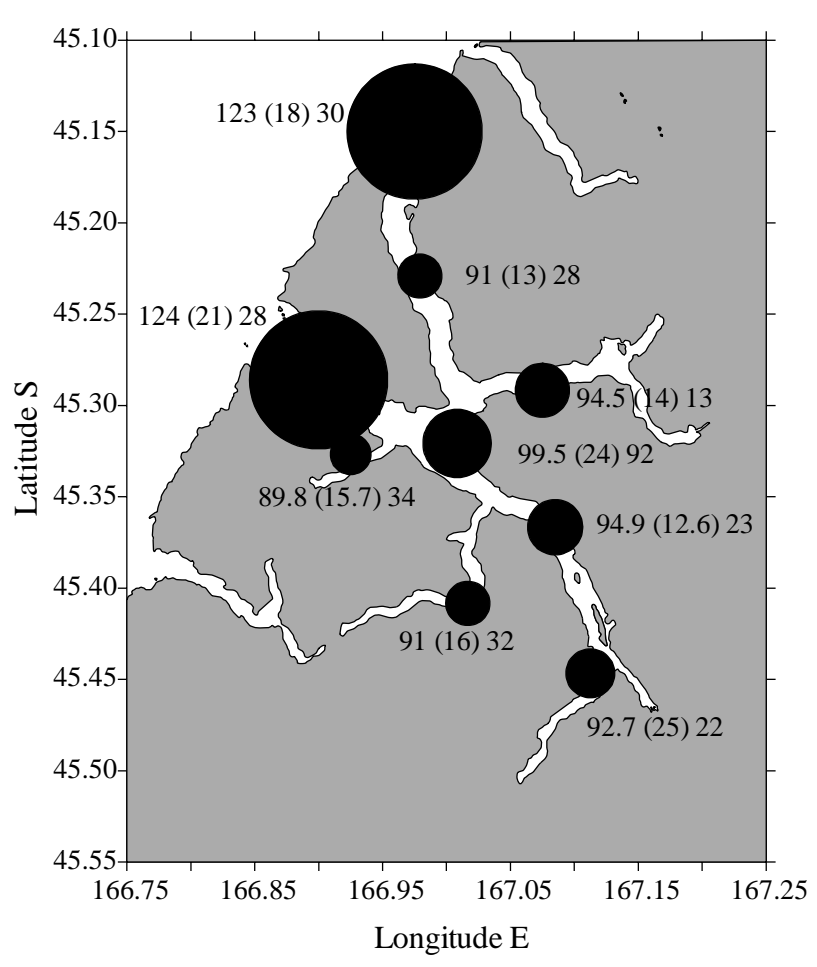

Fig. 4. Evechinus chloroticus. $L_{\infty}$ from the von Bertalanffy growth equation with variance in $L_{\infty}$ across the 9 study sites in Doubtful-Thompson Sound. Numbers indicate: $L_{\infty}$ (SE) sample size. Diameter of circles is proportional to mean of $L_{\infty}$

would be expected from a nutritional influence on growth (von Bertalanffy $\mathrm{r}^{2}=0.50, \mathrm{p}=0.03$; von Bertalanffy with variance in $L_{\infty}, \mathrm{r}^{2}=0.48, \mathrm{p}=0.04$; Richards $\left.\mathrm{r}^{2}=0.45, \mathrm{p}=0.05\right)$.

\section{Gonadal index}

The gonadal index is an estimate of the mean expected weight of the gonad of individuals $100 \mathrm{~mm}$ in test diameter at each study site. We observed a seasonal change in gonadal indices as in past studies in Doubtful Sound (Lamare 1998). Here gonadal indices were low in the winter months and rose to peak values between November and January, during which time spawning occurred. Gonadal indices during the November to January period were large at the entrances of the fjord and at mid-fjord, and declined in the arms. The gonadal index had a negative correlation with the Aristotle's lantern index $\left(\mathrm{r}^{2}-0.50, \mathrm{p}=0.04\right)$. However, the pattern in the mean per-capita gonad weight was distinctly nonlinear, with large gonad weights at the 2 entrance sites and at Espinosa Point (Fig. 6). This pattern also correlated with the Aristotle's lantern index $\left(\mathrm{r}^{2}=0.67, \mathrm{p}=\right.$ 0.007), as would be expected by energetic limitations on growth and gamete production across the fjord.

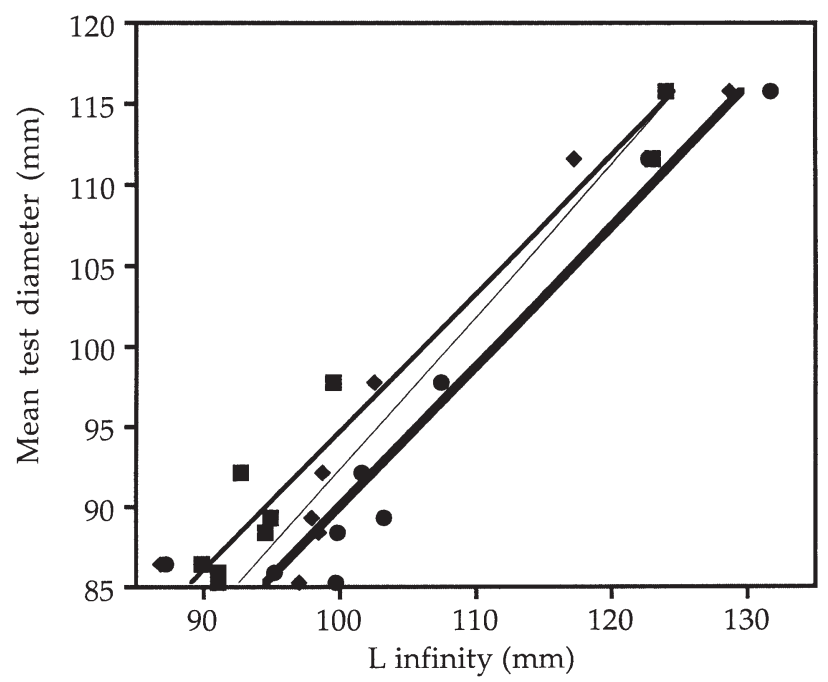

Fig. 5. Evechinus chloroticus. Relationship between mean test diameter $(\mathrm{mm})$ and $L_{\infty}(\mathrm{mm})$ for von Bertalanffy model $\left(\boldsymbol{\square}\right.$, medium line), von Bertalanffy model with variance in $L_{\infty}$ (•, bold line), and Richards model $(\bullet$, thin line), at 9 sites in Doubtful-Thompson Sound. $L_{\infty}$ for each of the growth models correlates with the mean size calculated from stable size frequency distributions (von Bertalanffy $\mathrm{r}^{2}=0.92, \mathrm{p}<0.0001$; von Bertalanffy with variance in $L_{\infty} \mathrm{r}^{2}=0.96, \mathrm{p}<0.0001$; Richards $\left.\mathrm{r}^{2}=0.90, \mathrm{p}<0.0001\right)$

\section{Abundance and depth distribution}

$90 \%$ of the sea urchin population was found between 3 and $9 \mathrm{~m}$ depth relative to mean high water, with peak abundance at 4 to $6 \mathrm{~m}$ (Fig. 7). The average depth of the 380 animals sampled in 596 quadrates was $6.0 \mathrm{~m}$. Estimates of abundance in the 3 to $9 \mathrm{~m}$ depth stratum at each site were intermediate at the entrances of the fjord, highest at mid-fjord and decreased in the arms (Fig. 8). Note that both mid-fjord sites in Doubtful Sound (Espinosa Point) and Thompson Sound supported a high abundance of sea urchins. Results from 1-way ANOVA on these data indicated significant differences among sites $\left(F_{8,1325}=55.15, \mathrm{p}=0.0001\right)$. Results from the Bonferroni post-hoc test indicated the differences that are statistically significant among pairwise comparisons (Table 5). The index of dispersion, $I=\left(s^{2} / x\right)$ $(n-1)$, is not significantly different from a $\chi^{2}$ distribution in Crooked Arm, but was significantly different at each of the other sites (Andrews \& Mapstone 1987). These results indicate that the variance-tomean ratio was significantly different than unity and individuals were over-dispersed to varying degrees at each site except Crooked Arm (Fig. 8). The variance-to-mean ratio was highest at the mid-fjord and entrance sites, and declined in the arms of the fjord (Fig. 8). 


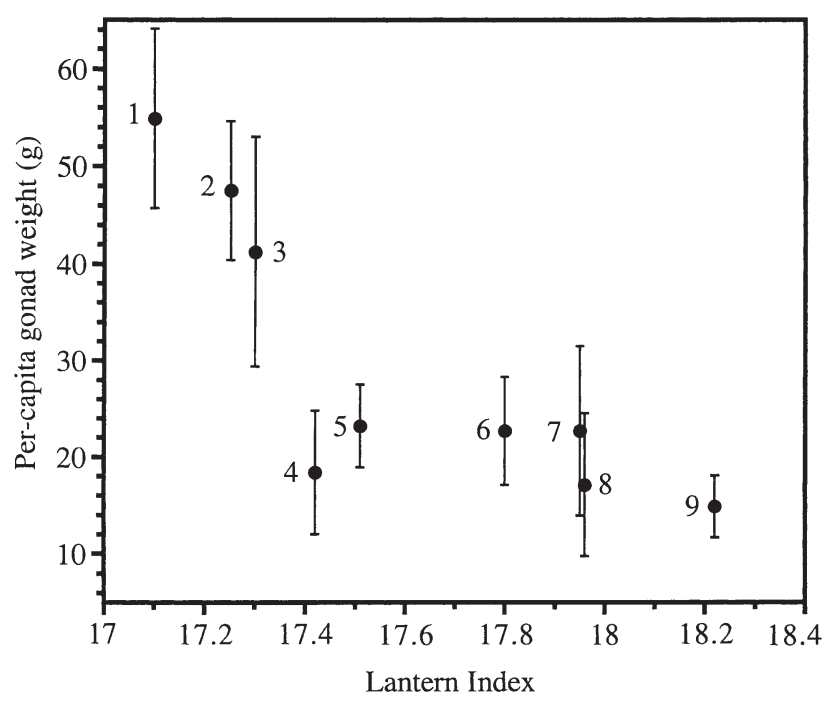

Fig. 6. Evechinus chloroticus. Per-capita gonad weight (g) versus Aristotle's lantern index across the 9 sites in DoubtfulThompson Sound, demonstrating the high gonad size at entrance sites and Espinosa Point where Aristotle's lantern indices indicate best nutritional history. Mean values \pm SE. Site numbers are (1) Thompson outer, (2) Corset Cove, (3) Espinosa Point, (4) Thompson inner, (5) Hall Arm, (6) First Arm, (7) Oz, (8) Bradshaw, and (9) Crooked Arm

\section{Larval settlement}

Over the 2 yr of monitoring, October 1997 through December 1999, settlement was relatively high at the mid-fjord sites of Doubtful Sound, but decreased toward the entrance and in the arms of the Sound. In Thompson Sound larval settlement was highest at the mid-fjord site and decreased at the entrance and at the Bradshaw Sound site. Most of the settlement observed occurred during a large event in December 1999 with several smaller settlement events during the other time periods. We observed a mass spawning of sea urchins on November 13, 1999 during a low spring tide, similar

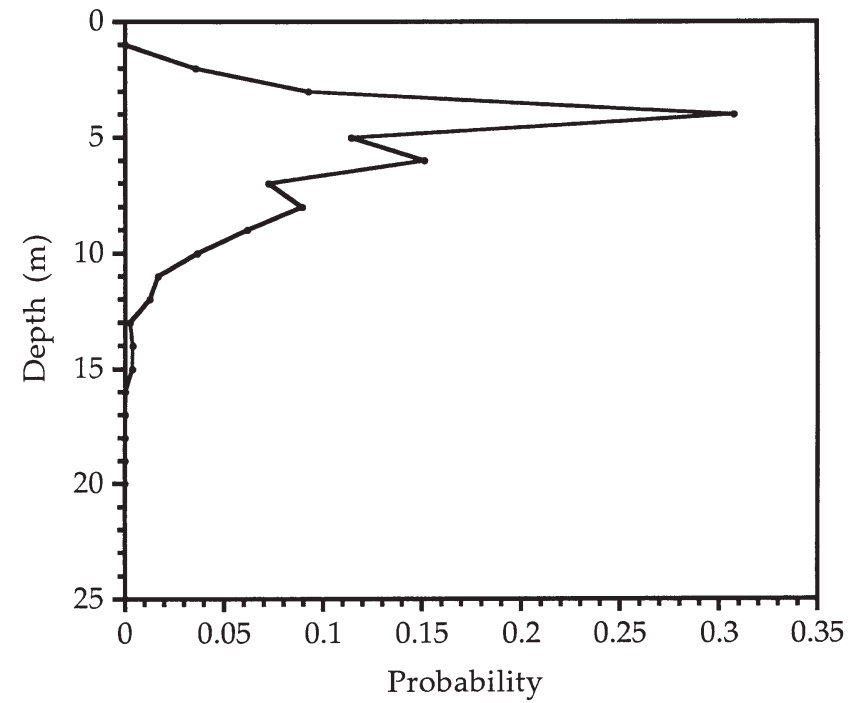

Fig. 7. Evechinus chloroticus. Probability distribution of sea urchin abundance across depth, indicating that $90 \%$ of sea urchins reside between 3 and $9 \mathrm{~m}$ depth. Pattern is based on abundance from $596 \times 1 \mathrm{~m}^{2}$ depth stratified quadrates from

10 sites along the axis of Doubtful Sound (see Fig. 1b)

to an event observed in 1997 (Lamare \& Stewart 1998). Approximately 60 to $70 \%$ of adult sea urchins were actively spawning during this time at 3 sites in Doubtful-Thompson Sound. The timing of the subsequent settlement event, observed in late December 1999, suggested that this cohort was a product of the observed spawning event. Mean settlement rate among sites was correlated with population density $\left(r^{2}=0.42, p=0.05\right)$ (Fig. 9).

\section{Hydrographic surveys}

The structure, variability and dynamics of the low salinity layer in Doubtful-Thompson Sound responded rapidly to strong wind and rain events (Gibbs et al.

Table 5. Probability values for Bonferonni post-hoc test on pair-wise comparisons of mean density. Significant differences are indicated in bold

\begin{tabular}{|llllllll|}
\hline & $\begin{array}{c}\text { Crooked } \\
\text { Arm }\end{array}$ & $\begin{array}{c}\text { Bradshaw } \\
\text { Sound }\end{array}$ & Oz & $\begin{array}{c}\text { First } \\
\text { Arm }\end{array}$ & $\begin{array}{c}\text { Hall } \\
\text { Arm }\end{array}$ & $\begin{array}{c}\text { Thompson } \\
\text { inner }\end{array}$ & $\begin{array}{c}\text { Espinosa } \\
\text { Point }\end{array}$ \\
Crooked Arm & & & & & & \\
Bradshaw Sound & $\mathbf{0 . 0 0 0 1}$ & & & & & \\
Cz & $\mathbf{0 . 0 0 0 1}$ & 1.0 & & & & \\
First Arm & 1.0 & $\mathbf{0 . 0 0 0 1}$ & $\mathbf{0 . 0 0 0 1}$ & & & \\
Hall Arm & $\mathbf{0 . 0 0 0 1}$ & 0.6717 & $\mathbf{0 . 0 4 6 5}$ & $\mathbf{0 . 0 0 0 1}$ & & \\
Thompson inner & $\mathbf{0 . 0 0 0 1}$ & $\mathbf{0 . 0 0 0 1}$ & $\mathbf{0 . 0 1 2 7}$ & $\mathbf{0 . 0 0 0 1}$ & $\mathbf{0 . 0 0 0 1}$ & & \\
Espinosa Point & $\mathbf{0 . 0 0 0 1}$ & 1.0 & 1.0 & $\mathbf{0 . 0 0 0 1}$ & $\mathbf{0 . 0 1 2 4}$ & $\mathbf{0 . 0 1 7 6}$ & 0.7100 \\
Corset Cove & $\mathbf{0 . 0 0 0 1}$ & $\mathbf{0 . 0 0 0 1}$ & 0.4803 & $\mathbf{0 . 0 0 0 1}$ & $\mathbf{0 . 0 0 0 1}$ & 1.0 & \\
Thompson outer & $\mathbf{0 . 0 0 0 1}$ & 1.0 & 1.0 & $\mathbf{0 . 0 0 0 1}$ & 1.0 & $\mathbf{0 . 0 0 0 1}$ & 1.0 \\
\end{tabular}




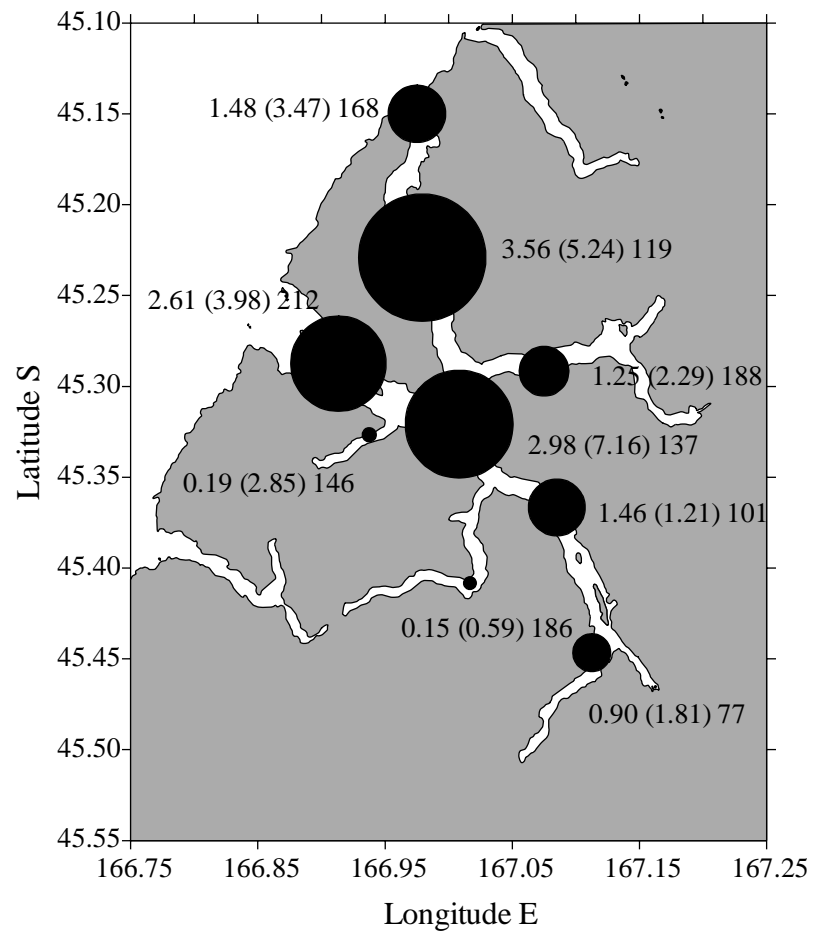

Fig. 8. Evechinus chloroticus. Abundance of adult sea urchins (ind. $\mathrm{m}^{-2}$ ) across the 9 study sites in Doubtful-Thompson Sound. Numbers indicate: mean abundance (varianceto-mean ratio) sample size (number of $2 \mathrm{~m}^{2}$ quadrates placed at each site). Diameter of circles is proportional to mean abundance

2000). Here we present 2 synoptic views of the spatial structure of the low salinity layer to give insight into the near surface gradient in the fjord and sensitivity of the low salinity layer to rainfall.

Patterns in average salinity for the upper $2 \mathrm{~m}$ of the water column across Doubtful-Thompson Sound during a period of high average rainfall (September 27 through October 9, 1997) show strong gradients in surface salinity with values ranging from 0.0 to 34 (Fig. 1a). Average rainfall at the NIWA weather station on Secretary Island during September 27 through October 9, 1997 was $17.0 \mathrm{~mm} \mathrm{~d}^{-1}$. The pattern indicates low salinity waters at the tailrace of the HEP and in the arms of Doubtful-Thompson Sound. Salinity increased in the surface layer towards the entrance of Doubtful Sound as the seaward flowing low salinity layer thinned and mixed with seawater. The average salinity for the upper $2 \mathrm{~m}$ of the water column during a period of low rainfall (January 27 through February 10, 1999) shows relatively high surface salinity extending into Thompson and Bradshaw Sounds (>30) but low salinity (11 to 14 ) associated with the relatively constant hydroelectric plant outflow in Doubtful Sound (Fig. 1b). The average rainfall at the Secretary Island

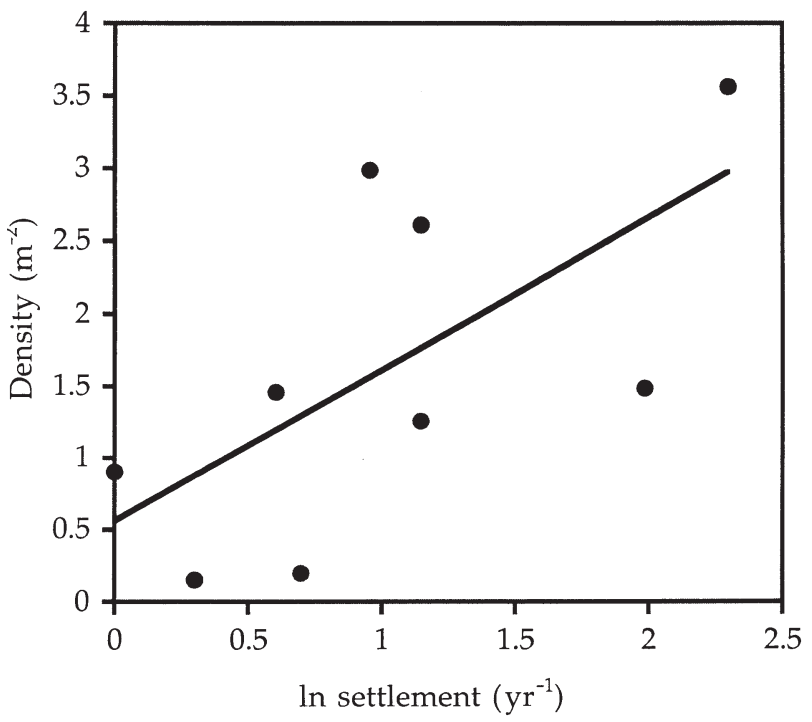

Fig. 9. Evechinus chloroticus. Relationship between the natural logarithm of yearly settlement rate (per sample unit) over the 2 yr period between January 1997 and January 1999 and abundance of adult sea urchins $\left(y=0.561+1.048 x, r^{2}=0.42\right.$, $\mathrm{p}=0.05)$

weather station for January 27 through February 10, 1999 was $3.0 \mathrm{~mm} \mathrm{~d}^{-1}$.

An example of rainfall and temperature at $2 \mathrm{~m}$ depth from June 14 through October 20, 2000 from the site at Hall Arm shows the response of the relatively cold (8 to $11^{\circ} \mathrm{C}$ ) low salinity layer to storm events. In this series the underlying seawater of salinity 32 to 34 remained at 11 to $15^{\circ} \mathrm{C}$ (Fig. 10). These insights into the structure and dynamics of the low salinity layer provided a basis, and data, for forcing functions in the hydrodynamic model.

\section{Hydrodynamic model methods}

We evaluated passive dispersal patterns in Doubtful Sound using a 3D primitive-equation hydrodynamic model, developed by Dietrich et al. (1987), and modified by Gibbs et al. (2000), to simulate the distribution and pattern of accumulation of passive particles arising in different regions of the fjord. Details of the configuration, initialization and boundary conditions for the hydrodynamic model can be found in Appendix 1. Gibbs et al. (2000) have shown that the model is able to accurately determine the response of the nearsurface waters of the fjord to winds, rainfall and input of freshwater from the hydroelectric power plant. Gibbs et al. (2000) validated the hydrodynamic model by hindcasting the thermohaline response to real winds, rain and tailrace discharge and comparing the model hindcasts to hydrographic data acquired from 


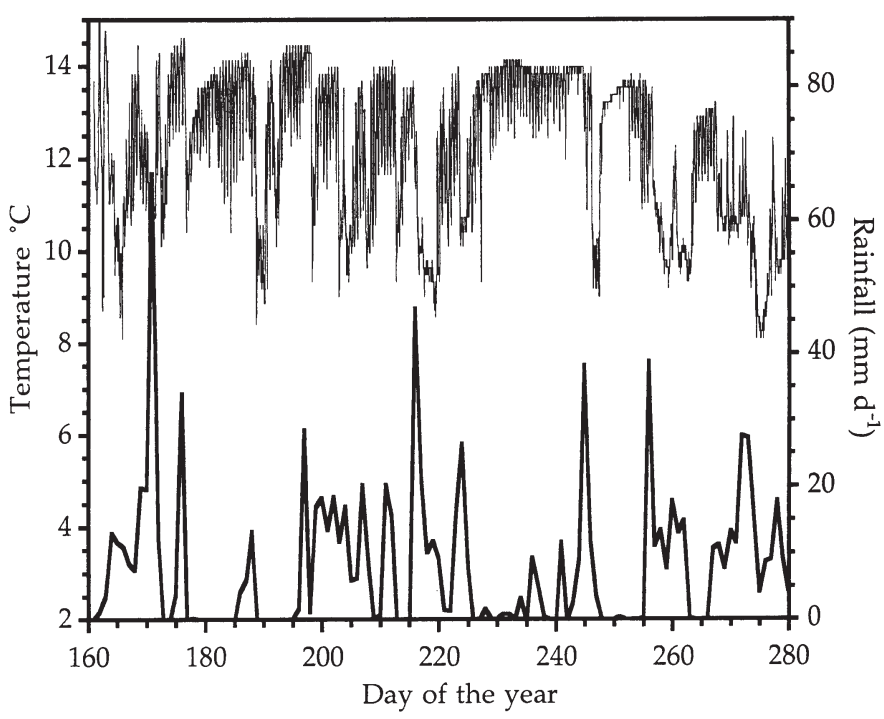

Fig. 10. Time series of rainfall (bold line) at Secretary Island weather station $\left(\mathrm{mm} \mathrm{d}^{-1}\right)$ and temperature $\left({ }^{\circ} \mathrm{C}\right)$ at a depth of $2 \mathrm{~m}$ at the Hall Arm site (thin line) for June 14 through October 20,2000, indicating variation in the depth of the cold low salinity layer $\left(8\right.$ to $11^{\circ} \mathrm{C}$ ) in response to high rainfall events

4 semi-permanent oceanographic moorings deployed in the fjord system.

We forced the model with idealized wind and rain scenarios and investigated the resulting distributions of passive particles. At each time step we extinguished the passive particles found in water of salinity below 28 (after Pearse \& Cameron 1991). These results were then used to interpret observed patterns in gamete production and settlement.

\section{DISCUSSION}

The spatial structure in growth and reproduction within the Evechinus chloroticus population in Doubtful-Thompson Sound supports the idea that this population consists of areas of reproductive source and sink at the scale of $10 \mathrm{~s}$ of $\mathrm{km}$. Adult growth rates differ markedly among sites, suggesting that growth may be energetically limited in the fjord complex. Evidence comes from patterns in the Aristotle's lantern index, an indicator of nutritional history, which demonstrates a gradient along the axis of the fjord. Sites at the entrances of Doubtful Sound and Thompson Sound and at Espinosa Point have low Aristotle's lantern indices relative to the other sites. This pattern is consistent with results from calorific studies of sea urchin diet in the Sound that have shown higher calorific intake by sea urchins living at the entrances of the Sound, where there are abundant populations of laminarian algae, than at inner sites where these algae are less common (Wing et al. 2001). Diet at inner fjord sites is likely influenced by a combination of poor food quality and the restriction of stenohaline species from the shallow subtidal by the low salinity layer (Witman \& Grange 1998).

Size distributions of adult sea urchins were stable over the 2 yr study. Therefore we can assume that for this study period differences in the shape of size distributions among sites will be determined by differences in size-specific growth and mortality and not by time varying recruitment (Botsford et al. 1994). We find that $96 \%$ of the variance in mean size among sites can be explained by variance in $L_{\infty}$ indicating that growth, rather than mortality, has likely influenced the patterns in size. Furthermore, both the patterns in mean test diameter and growth are consistent with the patterns in the Aristotle's lantern index, as would be expected if growth was energetically limited (e.g. Ebert 1980a, McShane \& Anderson 1997).

Gonadal indices during the November-January peak of the seasonal cycle also follow this spatial pattern, being high at the entrances and at Espinosa Point and low at the other sites. The consistently low values of the gonadal index in the arms of the fjord indicate low gamete production. Spatial patterns in the per-capita gonad weight are consistent with an energetic influence on both growth and gonad production among study sites (Thompson 1982, Andrew 1986, McShane et al. 1996). The sites where sea urchins grow to large sizes have an average per capita gonad weight of $47.86 \mathrm{~g}$, almost 2 and a half times the average of $19.83 \mathrm{~g}$ for the other sites.

Together these spatial patterns in growth and apparent gamete production indicate that per-capita reproductive contribution varies between regions. If sea urchins in Doubtful-Thompson Sound are contributing to a single larval pool, and larval survival is not significantly different between different parts of the fjord, as has been documented by larval dispersal studies (Lamare 1998, Lamare \& Barker 1999), then per-capita contribution to that larval pool based on per-capita gamete production could vary by a factor of almost 4 among sites. It is important to point out, however, that pre-dispersal density dependence in the form of depensatory effects on fertilization success may be important in this species (e.g. Levitan et al. 1992, Quinn et al. 1993). This Allee effect is influenced by density and aggregation of adults (Levitan et al. 1992 ) and by small scale mixing (Denny \& Shibata 1989), and could reduce the per-capita reproductive contribution from some regions of the fjord where gamete production is low and individuals are widely dispersed. The pattern in the index of dispersion $(I)$ 
across the fjord suggests that adult sea urchins are most aggregated at the $2 \mathrm{~m}^{2}$ spatial scale at entrance and mid-fjord sites. Note that the 3 sites with highest per-capita gonad size also have relatively aggregated distributions.

During the study we observed covariance of settlement rate and adult abundance among sites, suggesting that spatial patterns in adult abundance may be influenced by spatial patterns in larval supply. The spatial patterns in larval settlement across the fjord suggest that larvae are retained, and settle in greatest numbers at mid-fjord. Moreover, the temporal pattern of settlement events relative to spawning events suggests seasonal retention of a single cohort of larvae in the Sound, as observed previously in Doubtful Sound (Lamare 1998).

To further investigate the spatial relationship between gamete production and larval settlement, and between larval settlement and adult abundance, we used an empirically validated 3D hydrodynamic model of Doubtful-Thompson Sound to test the influence of patterns in larval production, development time and wind/rain event magnitude on distribution of passive particles throughout the Sound. We used passive particles as a proxy for the transport of sea urchin larvae around the fjord. The use of the numerical hydrographic model here is not to accurately predict the flow paths of individual larvae in the fjord. Rather, the model is used to elucidate the dominant physical processes influencing larval dispersal. In this context, use of the model for investigating dispersal of sea urchin larvae is appropriate as they have a typical larval duration of 18 to $30 \mathrm{~d}$ (Lamare 1998). With this relatively long larval duration it is likely that dispersal is primarily influenced by the mean estuarine circulation. In contrast, dispersal of species with a shorter larval duration would be influenced by higher-frequency stochastic variability associated with strong wind/rain events, rather than the background estuarine circulation. In order to elucidate the response of the passive particle transport paths to estuarine and wind forced circulation, simulations with different physical forcing regimes, in addition to different patterns in particle production, were investigated (Fig. 11a,b).

In the first scenario we added particles to the model in proportion to per-capita gonad size in each of the 9 study regions of the Sound. This scenario represents a case where larval production is linearly related to per-capita gamete size. The distribution of particles after $30 \mathrm{~d}$ in the model with moderate wind/rain $\left(0.4 \mathrm{~Pa} / 5 \mathrm{~mm} \mathrm{~h}^{-1}\right)$ is shown in Fig. 11a. The passive particles were accumulated in high concentrations near the head of the fjord. This demonstrates that the weak mean estuarine circulation influenced dispersal of passive particles throughout the fjord and tended to retain particles in the inner regions. The low concentrations of particles at the entrances is a result of losses to the open ocean during peaks of the wind forcing events when the flow beneath the low salinity layer was in the seaward direction. The spatial pattern of passive particles in model runs with strong wind/rain forcing (0.6 to $0.8 \mathrm{~Pa} / 7$ to $10 \mathrm{~mm} \mathrm{~h}^{-1}$ ) was qualitatively similar to Fig. 11a (not shown). However, more larvae were lost to the low salinity layer through enhanced vertical mixing.

Fig. 11b shows the distribution of passive particles after $30 \mathrm{~d}$ in the model, where the particles were seeded only at the entrances and Espinosa Point. This second scenario approximates a case where there is a non-linear interaction between aggregation and larval production among sites (i.e. an Allee effect). In this run the wind/rain forcing was identical to the first scenario. During the $30 \mathrm{~d}$ period, passive particles were gradually advected throughout the fjord by the mean estuarine circulation, but became most concentrated at midfjord. Advective losses of particles at the entrances and to the low salinity layer occurred during periods when seaward flows in the oceanic layer beneath the low salinity layer were driven by strong wind events. The resulting pattern in particle supply closely matches our empirical observations of larval settlement and adult density (Fig. 9).

We performed additional model runs to test the sensitivity of the results shown in Fig. 11b to a range of wind/rain forcing regimes and different mean larval durations. The results from these simulations, where the wind stress was varied between 0 and $0.8 \mathrm{~Pa}$ (and the rainfall varied in proportion to the wind stress, 0 to $10 \mathrm{~mm} \mathrm{~h}^{-1}$ ) and mean larval duration varied between 18 and 30 d, may be seen in Fig. 12 . In this figure the simple linear correlation coefficient $\mathrm{R}(\mathrm{x})$ (Sokal \& Rohlf 1981) between the passive particle concentrations at the 9 sites and adult abundance as a function of the wind stress is shown. The standard error of this relationship is calculated among model runs with larval duration between 18 and $30 \mathrm{~d}$ (Fig. 12). Clearly the closest coherence between the simulated larval dispersal and adult abundance occurs at intermediate wind stress (magnitude 0.4 to $0.6 \mathrm{~Pa}$ ). In simulations with light winds (0 to $0.2 \mathrm{~Pa}$ ), the weak estuarine circulation was not sufficient to advect passive particles very far into the fjord. In contrast, during simulations with strong wind forcing $(0.8 \mathrm{~Pa})$, total concentrations of passive particles after $30 \mathrm{~d}$ were very low as a result of high losses through vertical mixing of particles into low salinity water and alongshore advection of mixed surface water at the fjord entrances. 

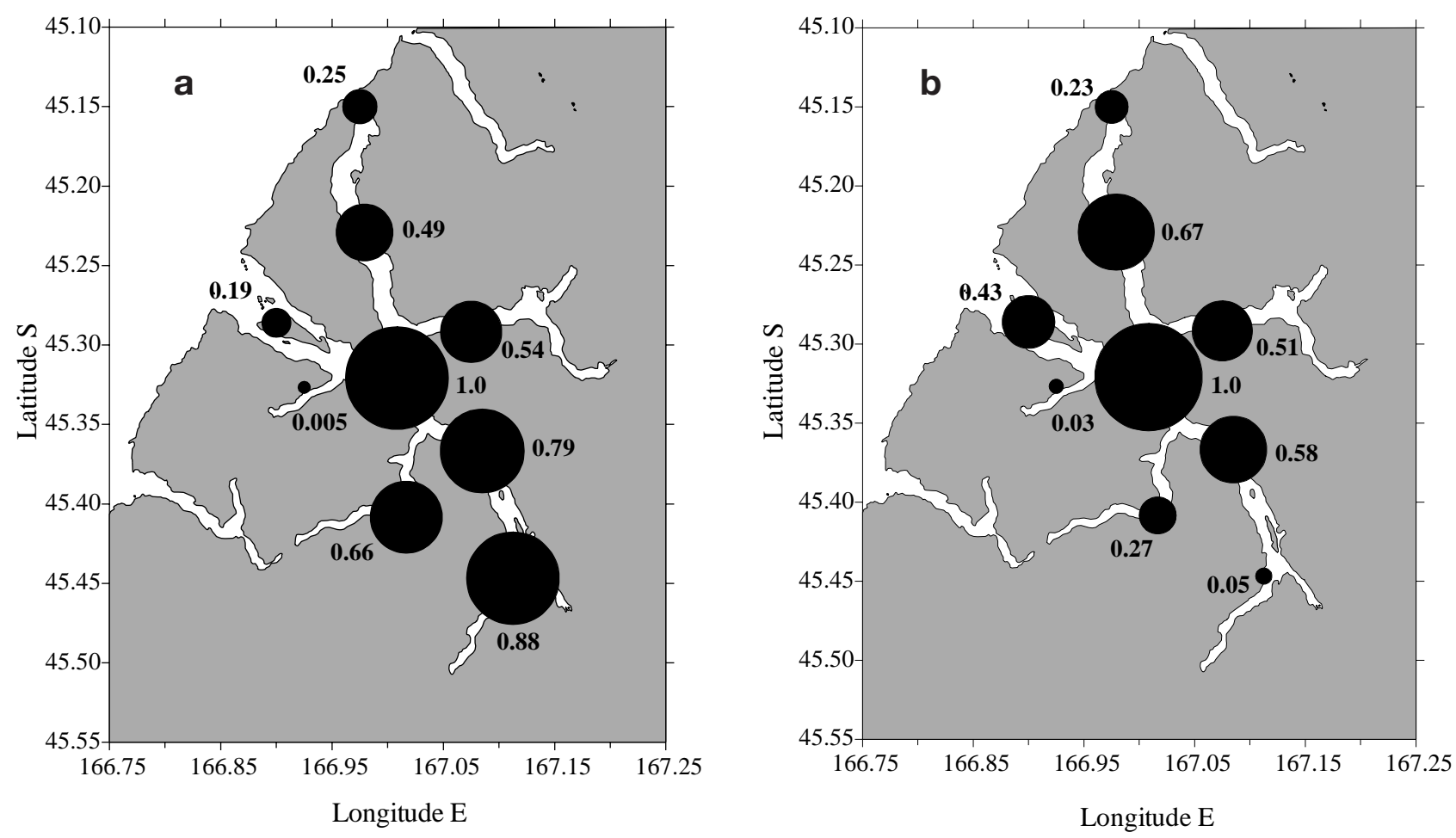

Fig. 11. Evechinus chloroticus. Predicted concentrations of larvae in the hydrodynamic model after $30 \mathrm{~d}$ for (a) particle production at all sites in the Sound in proportion to the observed per-capita E. chloroticus gonad size and (b) particle production at the entrance sites and Espinosa Point, demonstrating only the effects of spatial patterns in larval production on dispersal. Numbers indicate relative concentrations of passive particles

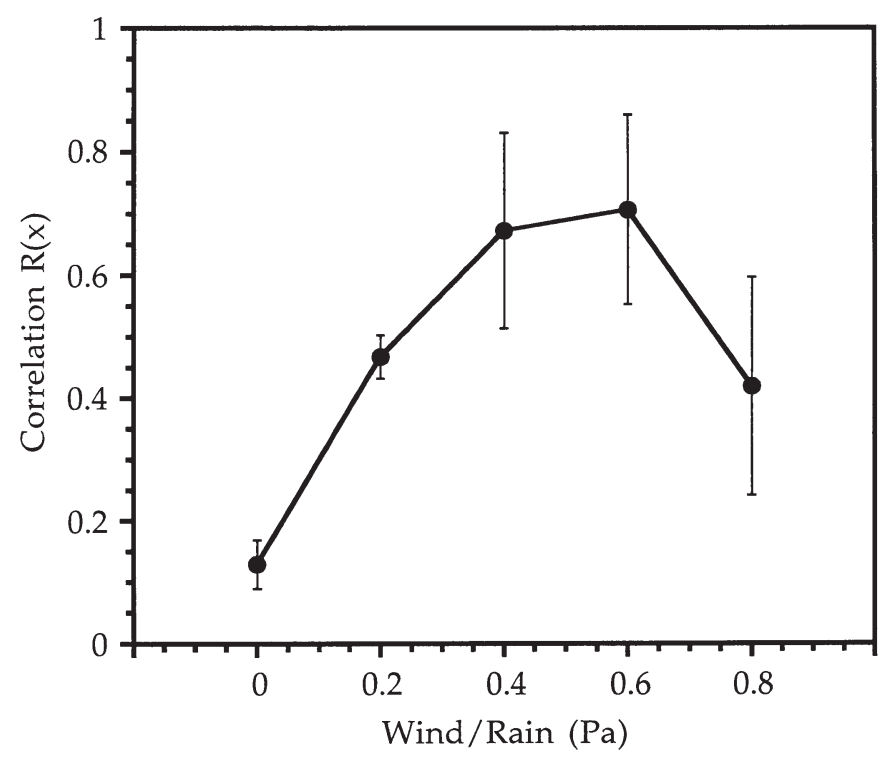

Fig. 12. Correlation between particle concentration at each site in the hydrodynamic model and observed abundance of adult sea urchins Evechinus chloroticus at each site, demonstrating the sensitivity of dispersal patterns to larval duration and the physical forcing regime. Particles are produced at the entrances of the fjord and mid-fjord in Doubtful Sound only. SE of the correlation statistic indicates variability from different larval duration in the model from 18 to $30 \mathrm{~d}$
Several caveats must accompany conclusions drawn from the modeled transport patterns. This model has provided us with a formal numerical framework with which to evaluate the possible consequences of the observed differences in per-capita gamete production to patterns in larval dispersal and supply within this system. Our analysis does not discount the possibility that local populations of sea urchins are self-seeding; it only provides the physical basis for the hypothesis that they exist as reproductive sources and sinks. As such it has defined the possibility that patterns in adult abundance can be explained by larval supply when larval production is restricted to a small area of high gamete production relative to the total area of the population. That is a strong reproductive source/sink structure in the population.

While settlement driven abundance may explain the observed patterns, several alternative mechanisms may contribute. The patterns that we observe in adult abundance could be explained by differences in postsettlement mortality. Studies of early post-settlement mortality in North American sea urchins Strongylocentrotus franciscanus and S. purpuratus have shown that mortality may differ markedly between kelp-dominated and barren-area sites (Rowley 1990). For Evechinus chloroticus, Andrew \& Choat (1982) found large 
differences in outplanted juvenile survival between deep reef, coraline flat and Ecklonia radiata forest habitats. In Doubtful Sound, Lamare \& Barker (1999) observed differences in juvenile survival associated with depth. However, site specific differences have not been found.

A second possibility is that patterns in adult abundance could be explained by adults consistently moving towards the mid-fjord sites. If this were the case we would expect high tag recovery at the low density sites and lower recovery rates at the high density sites. However, we do not observe this pattern in tag recovery. Lamare \& Mladenov (2000) observed a $37 \%$ tag recovery rate after $1 \mathrm{yr}$ and a $30 \%$ recovery rate after $4 \mathrm{yr}$ at a mid-fjord site. Dispersion studies of Evechinus chloroticus confirm that although movement rates can vary with food availability, there is no evidence for consistent directional movement of adults (Andrew \& Stocker 1986). It is therefore unlikely that the observed patterns in abundance can be attributed to adult movement.

Our empirical findings and model of dispersal suggest that the sea urchin population in the DoubtfulThompson Sound complex is likely a highly structured metapopulation with large and consistent differences in abundance, growth, gamete production and larval settlement between sites. Because patterns of peak abundance and gamete production do not overlap yet, it has been demonstrated that subpopulations share a single larval pool, it is likely that inner-fjord subpopulations form reproductive sinks, and that those populations with high gamete production near the fjord entrances form larval sources. As a consequence, the dynamics of this population, and others with a similar structure, may be particularly sensitive to influences on adult abundance within the source regions (e.g. Pullium 1988, Quinn et al. 1993). This would include exploitation, habitat degradation and changes in larval transport through changes in the hydrodynamic environment. These findings have important consequences for our understanding of population structure of meroplanktonic organisms living in the New Zealand fjords and for spatial management and conservation in this system.

Acknowledgements. We gratefully acknowledge those who were instrumental in making this work possible: Paul Meredith, Bob Walker, Mattias Sköld, Lindsay Chatterton, Nicole Goebel, Jason Vasques, Barry Smith, Jim Leichter, Jennifer Diehl and the participants in Subtidal Ecology of Southern New Zealand (MARI 432). The University of Otago, the Royal Society of New Zealand, the Department of Conservation, National Institute for Water and Atmosphere New Zealand, Fjordland Travel and the Southland Trust provided monetary and logistic support for this work. We thank Drs Malcolm Bowman and David Dietrich for initial hydrodynamic model development.
Appendix 1. The hydrographic model was constructed from the DieCAST ocean model (Dietrich et al. 1987), which has been successfully applied to many coastal regions (e.g. Dietrich 1996). DieCAST has a good track record in simulating regions of steep bathymetry and hence was deemed to be the most suitable for DoubtfulThompson Sound. In the horizontal plane DieCAST uses a modified Arakawa 'a' grid and for Doubtful-Thompson Sound an orthogonal cartesian grid with dimensions of $200 \times 200 \mathrm{~m}$ was used. In the vertical dimension the model uses $20 \mathrm{z}$-levels. These were concentrated near the surface (the top grid cell was only $43 \mathrm{~cm}$ thick) in order to resolve the low salinity layer. Bottom friction was introduced according to a quadratic bottom stress formulation and a stair step approximation of the local bathymetry. DieCAST is a rigid lid model and does not use a turbulence closure scheme. Rather, the model uses high vertical resolution near the surface to adequately simulate nearsurface processes. The vertical mixing parameterization of Pacanowski \& Philander (1981) was used to control the turbulent eddy viscosity and diffusion terms.

The Doubtful-Thompson Sound model was forced by topographically steered along-fjord winds, freshwater entering the fjord at 142 rivers and the Manapouri hydroelectric powerplant tailrace at Deep Cove. The tailrace input was maintained at the hydroelectric powerplant operating discharge of $450 \mathrm{~m}^{3} \mathrm{~s}^{-1}$. The magnitude of the wind stress and rainfall consisted of a sinusoidal signal of period $4.5 \mathrm{~d}$. This represents 6.5 equally spaced idealized up-fjord directed wind/rain events over a $30 \mathrm{~d}$ period. Open ocean boundaries at the entrance of Doubtful and Thompson Sounds allowed climatological Tasman Sea water to enter the fjord when required. Forty-day simulations were used in this study and the fjord was initially filled with climatological oceanic water. The model was then started from rest and during the first $10 \mathrm{~d}$ of the simulation only the tailrace was applied. By Day 11 the model was stable under the influence of the tailrace, and winds and rainfall were then applied. Passive particles were injected into particular grid cells during Day 11 and tracked for the remainder of the simulation.

\section{LITERATURE CITED}

Andrew NL (1986) The interaction between diet and density in influencing reproductive output in the echinoid Evechinus chloroticus (Val.). J Exp Mar Biol Ecol 97:63-79

Andrew NL, Choat JH (1982) The influence of predation and conspecific adults on the survivorship of juvenile Evechinus chloroticus (Echinoidea: Echinometridae). Oecologia 54:80-87

Andrew NL, MacDiarmid AB (1991) Interrelations between sea urchins and spiny lobsters in northeastern New Zealand. Mar Ecol Prog Ser 70:211-222

Andrew NL, Mapstone BD (1987) Sampling and the description of spatial pattern in marine ecology. Oceanogr Mar Biol Annu Rev 25:39-90

Andrew NL, Stocker LJ (1986) Dispersion and phagokinesis in the echinoid Evechinus chloroticus (Val.). J Exp Mar Biol Ecol 100:11-23

Ayling AM (1981) The role of biological disturbance in temperate subtidal encrusting communities. Ecology 62: $830-847$ 
Botsford LW, Smith BD, Quinn JF (1994) Bimodality in size distributions: the red sea urchin as an example. Ecol Appl $4: 42-50$

Carpenter RC (1990) Mass mortality of Diadema antillarum. Mar Biol 104:67-77

Denny MW, Shibata MF (1989) Consequences of surf-zone turbulence for settlement and external fertilization. Am Nat 134:859-889

Dietrich DE (1996) Application of a modified Arakawa 'a' grid ocean model having reduced numerical dispersion to the Gulf of Mexico circulation. Dyn Atmos Oceans 27:201-217

Dietrich DE, Marietta MG, Roache PJ (1987) An ocean modeling system with turbulent boundary layers and topography: numerical description. Int J Numer Methods Fluids 7 : 833-855

Dix TG (1970a) Biology of Evechinus chloroticus (Echinoidea: Echinometridae) from different localities. 1. General. NZ J Mar Freshw Res 4:91-116

Dix TG (1970b) Biology of Evechinus chloroticus (Echinoidea: Echinometridae) from different localities. 3. Reproduction. NZ J Mar Freshw Res 4:385-405

Ebert TA (1980a) Flexible growth of sea urchin jaws: an example of plastic resource allocation. Bull Mar Sci 30: 467-474

Ebert TA (1980b) Estimating parameters in a flexible growth equation, the Richards function. Can J Fish Aquat Sci 37 : 687-692

Fletcher WJ (1987) Interactions among subtidal Australian sea urchins, gastropods, and algae: effects of experimental removals. Ecol Monogr 57:89-109

Gibbs MT, Bowman MJ, Dietrich DE (2000) Maintenance of near-surface stratification in Doubtful Sound, a New Zealand fjord. Estuar Coast Shelf Sci 51(6):683-704

Harrold C, Lisin S, Light K, Tudor S (1991) Isolating settlement from recruitment of sea urchins. J Exp Mar Biol Ecol 147:81-94

Lamare MD (1998) Origin and transport of larvae of the sea urchin Evechinus chloroticus (Echinodermata: Echinoidea) in a New Zealand fjord. Mar Ecol Prog Ser 174: $107-121$

Lamare MD, Barker MF (1999) In situ estimates of larval development and mortality in the New Zealand sea urchin Evechinus chloroticus (Echinodermata: Echinoidea). Mar Ecol Prog Ser 180:197-211

Lamare MD, Mladenov PV (2000) Modelling somatic growth in the sea urchin Evechinus chloroticus (Echinoidea: Echinometridea). J Exp Mar Biol Ecol 243:17-43

Lamare MD, Stewart BG (1998) Mass spawning by the sea urchin Evechinus chloroticus (Echinodermata: Echinoidea) in a New Zealand fjord. Mar Biol 132:135-140

Levitan DR (1992) Community structure in times past: influence of human fishing pressure on algal-urchin interactions. Ecology 73:1597-1605

Levitan DR, Sewell MA, Chia FS (1992) How distribution and abundance influence fertilization success in the sea urchin Strongylocentrotus franciscanus. Ecology 73:248-254

McShane PE, Anderson OF (1997) Resource allocation and growth rates in the sea urchin Evechinus chloroticus (Echinoidea: Echinometridae). Mar Biol 128:657-663

McShane PE, Gerring PK, Anderson OF, Stewart RA (1996) Population differences in the reproductive biology of Evechinus chloroticus (Echinoidea: Echinometridae). NZ J Mar Freshw Res 30:333-339

Editorial responsibility: Otto Kinne (Editor), Oldendorf/Luhe, Germany
Miller RJ, Colodey AG (1983) Widespread mass mortalities of the Green Sea Urchin in Nova Scotia, Canada. Mar Biol 73:263-267

Mladenov PV, Allibone RM, Wallis GP (1997) Genetic differentiation in the New Zealand sea urchin Evechinus chloroticus (Echinodermata:Echinoidea). NZ J Mar Freshw Res 31:261-269

Morgan LE, Botsford LW, Wing SR, Smith BD (2000) Spatial variability in growth and mortality of the red sea urchin, Strongylocentrotus franciscanus, in northern California. Can J Fish Aquat Sci 57:980-992

Pacanowski RC, Philander SGH (1981) Parameterisation of vertical mixing in numerical models of tropical oceans. J Phys Oceanogr 11:1443-1451

Pearse JS, Cameron RA (1991) Echinodermata: Echinoidea. In: Giese AC, Pearse JS, Pearse VB (eds) Reproduction of marine invertebrates, Vol 6. The Boxwood Press, Pacific Grove, CA, p 513-662

Pearse JS, Hines AH (1979) Expansion of a central California kelp forest following the mass mortality of sea urchins. Mar Biol 51:83-91

Pulliam HR (1988) Sources, sinks and population regulation. Am Nat 132:652-661

Quinn JF, Wing SR, Botsford LW (1993) Harvest refugia in marine invertebrate fisheries: models and applications to the Red Sea Urchin, Strongylocentrotus franciscanus. Am Zool 33:537-550

Raymond BG, Scheibling RE (1987) Recruitment and growth of the sea urchin Strongylocentrotus drobachiensis (Muller) following mass mortalities off Nova Scotia, Canada. J Exp Mar Biol Ecol 108:31-54

Rowley RJ (1990) Newly settled sea urchins in a kelp bed and urchin barren ground: a comparison of growth and mortality. Mar Ecol Prog Ser 62:229-240

Sainsbury KJ (1980) Effect of individual variability on the von Bertalanffy growth equation. Can J Fish Aquat Sci 37: 241-247

Smith BD, Botsford LW, Wing SR (1998) Estimation of growth and mortality parameters from size frequency distributions lacking age patterns: the red sea urchin (Strongylocentrotus franciscanus) as an example. Can J Fish Aquat Sci 55:1236-1247

Sokal RR, Rohlf FJ (1981) Biometry: the principles and practice of statistics in biological research (2nd edn). WH Freeman, New York

Stanton BR, Pickard GL (1981) Physical oeanography of the New Zealand fjords. NZ Oceanogr Inst Mem 88:1-37

Thompson RJ (1982) The relationship between food ration and reproductive effort in the green sea urchin Strongylocentrotus droebachiensis. Oecologia 56:50-57

Walford LA (1946) A new graphical method for describing growth of animals. Biol Bull 90:141-147

Walker MM (1984) Larval life span, larval settlement, and early growth of Evechinus chloroticus (Valenciennes). NZ J Mar Freshw Res 18:393-397

Wing SR, Lamare MD, Vasques J (2001) Echinoderms. Population structure of sea urchins (Evechinus chloroticus) along gradients in benthic productivity in the New Zealand fjords. In: Barker MF (ed) Echinoderms 2000. Balkema, Rotterdam

Witman JD, Grange KR (1998) Links between rain, salinity, and predation in a rocky subtidal community. Ecology 79: 2429-2447

Submitted: May 7, 2002; Accepted: August 21, 2002

Proofs received from author(s): February 3, 2002 